\title{
IMPLEMENTASI PEMBINAAN DAN PENGAWASAN WARALABA DI BIMBINGAN BELAJAR PRIMAGAMA KOTA BATAM
}

\author{
Rahmi Ayunda* \\ Universitas Internasional Batam
}

\begin{abstract}
This thesis discusses the effectiveness of the development and supervision of franchises in Batam city. The formulation of the problem in this thesis is related to the effectiveness of article 14 and article 15 in the community, problems in the application of article 14 and article 15 as well as solutions in dealing with problems in the application of article 14 and article 15.

This thesis is included in the category of juridical-sociological research which in the method of conducting research is by examining secondary data first, then proceed with conducting research on primary data in the field by conducting interviews. Data were processed and analyzed using qualitative methods and conclusions were drawn descriptively.

Testing the effectiveness of the application of article 14 and article 15 of Government Regulation No. 42 of 2007 was carried out using the theory of legal effectiveness proposed by Soerjono Soekanto. From the effectiveness test using the theory, it was concluded that Article 14 and Article 15 have not been optimally and effectively implemented. Law Enforcement Factors are the main factors of the ineffectiveness of the implementation of Article 14 and Article 15. The Department of Industry and Trade and Energy of Mineral Resources in Batam City has never even provided guidance or supervision on tuition course in Batam city. The need to develop derivative rules in the form of Mayor Regulations becomes a recommendation in dealing with the problems discussed in this thesis.
\end{abstract}

Keywordsv: Application of law, Coaching, Supervision, Tuition course, Primagama, Batam city.

\begin{abstract}
Abstrak
Penulisan tesis ini membahas mengenai efektivitas pembinaan dan pengawasan waralaba di kota Batam. Yang menjadi perumusan masalah didalam tesis ini adalah terkait efektivitas pasal 14 dan pasal 15 di masyarakat, problematika dalam penerapan pasal 14 dan pasal 15 serta solusi dalam menghadapi problematika dalam penerapan pasal 14 dan pasal 15 .

Penulisan tesis ini masuk kedalam kategori penelitian yuridis-sosiologis yang mana dalam metode pelaksanaan penelitiannya dengan mengkaji data sekunder terlebih dahulu, kemudian dilanjutkan dengan megadakan penelitian terhadap data primer dilapangan dengan melakukan wawancara. Data diolah dan dianalisis dengan menggunakan metode kualitatif lalu ditarik kesimpulan yang dijabarkan secara deskriptif.
\end{abstract}

*Alamat Korespondensi : rahmi@uib.ac.id

JOURNAL OF LAW AND POLICY TRANSFORMATION 
Pengujian tingkat efektivitas penerapan pasal 14 dan pasal 15 dari Peraturan Pemerintah No 42 tahun 2007dilakukan dengan menggunakan teori efektivitas hukum yang dikemukan oleh Soerjono Soekanto. Dari uji efektivitas menggunakan teori tersebut, disimpulkan bahwa pasal 14 dan pasal 15 pelaksanaannya masih belum optimal dan efektif. Faktor Penegak Hukum menjadi faktor utama dari belum efektifnya penerapan pasal 14 dan pasal 15. Dinas Perindustrian dan Perdagangan dan Energy Sumber Daya Mineral Kota Batam belum pernah sekalipun melakukan pembinaan ataupun pengawasan terhadap bimbingan belajar di Kota Batam. Perlunya penyusunan aturan turunan berupa Peraturan Walikota menjadi rekomendasi dalam menghadapi problematika yang dibahas dalam tesis ini.

Kata kunci: Penerapan hukum, Pembinaan, Pengawasan, Bimbingan belajar Primagama kota Batam.

\section{A. Latar Belakang Masalah}

Konstitusi negara Indonesia yakni Undang - Undang Dasar Negara Republik Indonesia tahun 1945 mengamanahkan didalam pasal 33 ayat (4) yang berbunyi : "Perekonomian nasional diselenggarakan berdasarkan atas demokrasi ekonomi dengan prinsip keadilan, kebersamaan, efisiensi, berkelanjutan, berwawasan lingkungan, kemandirian serta dengan menjaga keseimbangan kemajuan dan kesatuan ekonomi nasional."

Ketentuan pasal ini jika dilaksanakan sebagaimana mestinya maka akan sangat berkontribusi baik sekali bagi kemajuan perekonomian negara Indonesia. Adapun bentuk dari usaha memajukan perekonomian negara ini para pengusaha terus berinovasi mengembangakan pola usahanya sehingga sering kita jumpai. pebisnis terus berinovasi dalam pengembangan usahanya yang salah satunya dengan metode franchise atau dikenal juga dengan sebutan waralaba.

Dengan adanya metode bisnis waralaba menimbulkan konsekuensi terhadap aspek hukum, sehingga memerlukan adanya aturan hukum terkait pengaturan bisnis waralaba ini agar tercapai cita hukum yakni kepastian, keadilan dan kemanfaatan bagi pihak. Salah satu bidang usaha yang juga dapat dikembangkan melalui metode waralaba adalah usaha pada sektor bimbingan belajar, kemudian disebut bimbel. Semakin banyaknya bimbel saat ini sebagai bukti bahwa tingkat permintaan pengguna jasa layanan pendidikan meningkat.

Di Indonesia aturan mengenai waralaba telah dimulai pada tanggal 18 Juni 1997, yaitu dengan dikeluakan Peraturan Pemerintah RI Nomor. 16 Tahun 1997 tentang Waralaba, yang kemudian 10 tahun berjalan Peraturan Pemerintah No. 16 tahun 1997 tentang Waralaba ini telah dicabut dan diganti dengan Peraturan Pemerintah Nomor 42 Tahun 2007 tentang Waralaba dengan pengaturan teknisnya termuat didalam Peratuan Menteri Perdagangan No : 53/M-DAG/PER/8/2012 Tentang Penyelenggaraan Waralaba.

Memperhatikan pasal 14 dan pasal 15 tersebut maka tentulah jika ketentuan pasal tersebut benar - benar terlaksana dengan optimal maka pelaku usaha kecil menengah yang ada di Batam berpotensi mengembangkan usahanya menjadi waralaba atau franchise yang pada akhirnya juga akan membuat perekonomian 
Batam menjadi semakin menggeliat dengan semakin bayaknya usaha masyarakat yang berkembang.

Didalam penjelasan dari Peraturan Pemerintah No 42 Tahun 2007 Tentang Waralaba untuk pasal 14 ini disebutkan bahwa pemerintah dan pemerintah daerah dalam memberikan pembinaan mengenai waralaba juga berperan membantu memberikan perkuatan permodalan yang mana maksud dari pemberian perkuatan permodalan ini adalah memberikan kemudahan bagi pelaku usaha waralaba untuk mendapatkan fasilitas kredit dan mendapatkan bunga.

Berangkat dari ketentaun pasal 14 dan 15 tersebut peneliti tertarik untuk melakukan penelitian apakah das sollen yang termaktub didalam ketentuan pasal 14 dan Pasal 15 PP No 42 Tahun 2007 telah berjalan dengan semestinya, apakah ada harmonisasi antara law in book dengan law in actionnya? Bergerak dari hal tersebut penulis tertarik untuk menysun penelitian dengan judul " IMPLEMENTASI PEMBINAAN DAN PENGAWASAN WARALABA BIMBINGAN BELAJAR PRIMAGAMA DI KOTA BATAM ".

\section{B. Rumusan Masalah}

Berlandaskan latar belakang yang telah penulis paparkan pada bagian awal penelitian ini, penulis mengemukakan tiga buah rumusan masalah seperti dibawah ini :

1. Apakah penerapan Peraturan Pemerintah Nomor. 42 Tahun 2007 telah efektif diterapkan terhadap pembinaan dan pengawasan waralaba di bimbingan belajar Primagama kota Batam?

2. Apa saja problematika dalam penerapan Peraturan Pemerintah Nomor. 42 Tahun 2007 terkait pembinaan dan pengawasan waralaba dibimbingan belajar Primagama kota Batam ?

3. Bagaimana solusi yang tepat untuk menyelesaikan problematika yang dihadapi terkait pembinaan dan pengawasan waralaba di bimbingan belajar Primagama kota Batam?

\section{Metode Penelitian}

Penelitian ini merupakan penelitian hukum empiris atau juga dikenal sebagai penelitian hukum yuridis-empiris, yakni suatu penelitian yang dilakukan untuk meneliti lebih detail bagaimana bekerjanya hukum di masyarakat. Sebab dalam penelitian hukum empiris ini meneliti mengenai individu dan dalam hubungan hidupnya dengan masyarakat maka penelitian jenis ini disebut juga sebagai penelitian hukum sosiologis. ${ }^{1}$ Sehingga dapat disimpulkan penelitian yang penulis susun ini masuk kedalam jenis penelitian yuridis-sosiologis.

Jenis data yang digunakan terdiri dari data primer dan data sekunder. Dalam pelaksanaan penelitian ini data sekunder dikaji terlebih dahulu kemudian

\footnotetext{
${ }^{1}$ Diakses dari: http://www.gurupendidikan.com/macam-macam-metode-penelitian-hukum/
} diunduh pada 2 Desember 2016 
dilanjutkan dengan melakukan penelitian dilapangan berupa wawancara untuk memperoleh data primer. Data primer mencakup data - data yang penulis peroleh secara langsung yaitu hasil wawancara dan untuk data sekunder didapat dari aturan perundang - undangan, buku - buku, jurnal maupun hasil penelitian.

Adapun teknik yang digunakan dalam pengumpulan data adalah dengan cara melakukan wawancara. Pengumpulan data dengan melakukan wawancara ini bertujuan untuk memperoleh informasi dari pihak - pihak yang terkait dengan topik penelitian yang diperlukan. Sedangkan untuk instrumen pengumpulan data yang diperlukan dalam penyusunan penelitian ini adalah alat perekam suara dan kamera untuk merekam gambar.

Dalam pemyusunan penelitian ini, peneliti melakukan pengumpulan data dengan cara melakukan wawancara tidak terstruktur. Yang mana peneliti secara langsung mewawancarai perwakilan dari dinas perindustrian dan perdagangan kota Batam, pihak kementrian perdagangan Republik Indonesia dengan tidak menetapkan pertanyaan yang spesifik atau dapat juga disebut sebagai wawancara bebas. Peneliti tidak menggunakan pedoman wawancara yang berisi pertanyaanpertanyaan spesifik, namun hanya memuat poin-poin penting dari masalah yang ingin digali dari responden.

Selain mengumpulkan data melalui wawancara, peneliti juga mengumpulkan data dengan melakukan studi dokumen. Adapun jenis studi dokumen yang peneliti lakukan adalah jenis studi dokumen sekunder. Yakni peneliti melakukan pengkajian dari data yang disajikan oleh pihak yang tidak secara langsung mengalami suatu peristiwa tertentu.

Data dianalisis secara deskriptif kualitatif Penelitian dengan metode analisis deskriptif kualitatif ini menginterpretasikan dan menyajikan data yang berkaitan dengan kondisi dari hasil penelitian secara apa adanya, sesuai dengan kondisi yang ditemui dilapangan. Masalah yang diteliti dalam penulisan penelitian dilakukan analisis dan diselidiki dengan metode komparasi.

\section{Hasil Penelitian dan Pembahasan}

1. Efektivitas Penerapan Peraturan Pemerintah No 42 Tahun 2007 tentang Waralaba Terhadap Pembinaan dan Pengawasan Waralaba dibidang Bimbingan Belajar di Kota Batam.

Indonesia merupakan negara hukum. Hal ini termaktub didalam konstitusi negara Indonesia Undang Undang Dasar Negara Republik Indonesia Tahun 1945 pasal 1 ayat (3) yang berbunyi, "Negara Indonesia adalah Negara hukum". Hal ini menimbulkan konsekuensi logis bahwa setiap tindak tanduk masyarakat maupun pemerintah haruslah sesuai dengan aturan yang ditetapkan didalam hukum positif. Sebagai negara kesejahteraan, peran serta negara dalam kehidupan masyarakat hampir mencakup kesegala aspek. Hal ini dilakukan sebagai wujud semata mata untuk mencapai kesejahteraan bagi masyarakat sebesar - besarnya. Termasuk didalamnya pemerintah juga turut serta dalam mengawasi dan memberikan 
pembinaan bagi usaha - usaha waralaba yang dibakukan kedalam suatu aturan perundang - undangan.

Lebih lanjut Soerjono Soekanto menyebutkan bahwa dalam sosiologi hukum masalah kepatuhan atau ketaatan hukum terhadap kaidah-kaidah hukum pada umumnya telah menjadi faktor yang pokok dalam mengukur efektif tidaknya sesuatu yang ditetapkan dalam hukum. Dari hasil wawancara yang penulis lakukan dapat dikatakan bahwa kepatuhan pemerintah kota Batam sebagai pelaksana dari pembinaan dan pengawasan terhadap waralaba sebagaimana diatur didalam pasal 14 PP No 42 Tahun 2007 tentang waralaba yang dijelaskan lebih rinci lagi dalam pasal 26 dan pasal 28 Peraturan Menteri Perdagangan No 58/M-DAG/PER/8/2012 tentang penyelenggaraan waralaba masih belum berjalan sebagaimana mestinya.

Dari hasil wawancara yang penulis lakukan terhadap pemangku kepentingan mengenai pembinaan dan pengawasan terhadap waralaba sebagaimana yang diatur pada pasal - pasal yang disebutkan diatas, dapat diketahui bahwa hal yang telah diatur oleh undang - undang belum terlaksana. Sehingga di dalam penerapan PP No 42 Tahun 2007 Tentang Waralaba yang dilakukan oleh instansi pemerintah kota Batam dalam hal ini Dinas Perindustrian, Perdagangan dan Energi Sumber Daya Mineral kota Batam dapat dilihat bahwa hukum yang berlaku tidak berjalan dengan sendirinya, sehingga harus didukung oleh fakor-faktor yang mempengaruhi agar terhadap suatu aturan dapat menjadi efektif sebagaimana yang dikemukakan oleh Soerjono Soekanto, setidaknya ada 6 faktor yang mempengaruhi efektifitas hukum yaitu :

\section{Faktor Hukum}

Jika bicara tentang hukum, tidak lepas dari tiga unsur utamanya yaitu keadilan, kepastian dan kemanfaatan. Dalam pelaksanaan hukum sehari harinya, tidak aneh ditemukan adanya pertentangan antara keadilan dan kepastian dalam hukum. Munculnya pertentangan antara kepastian dan keadilan dalam praktek dari penegakan hukum ini dikarenakan untuk kepastian hukum wujudnya nyata tertulis pasti sesuai dengan apa yang tercantum didalam undang - undang sedangkan jika kita berbicara tentang keadilan, ini merupakan hal yang abstrak, oleh sebab itu hakim ketika memutuskan perkara terkadang lebih mengutamakan kepada unsur kepastian hukumnya saja berpatokan kepada apa yang tertulis didalam undang undang saja, sehingga unsur keadilan menjadi terabaikan.

Dikaitkan dengan permasalahan dalam penulisan tesis ini, untuk menganalisis lebih mendalam terkait faktor hukumnya perlu dijabarkan terlebih dahulu bagaimana hukum positif di negara Indonesia mengatur mengenai pembinaan dan pengawasan waralaba di Indonesia.

Pasal 14 PP No 42 tahun 2007 tentang Waralaba pada Bab VI membahas tentang Pembinaan dan Pengawasan. Didalam bab ini secara pengaturan hukum untuk level Peraturan Pemerintah menurut pendapat penulis masih terdapat beberapa hal yang perlu untuk dikiritisi. 
Disebutkan didalam pasal 14 PP No 42/2007 bahwa yang bertanggung jawab melakukan pembinaan bagi waralaba adalah pemerintah dan pemerintah daerah. Dan hal - hal yang menjadi lingkup dari pembinaan yang dilakukan oleh pihak pemerintah ataupun pemerintah daerah adalah sebagai berikut ;

a. "Pendidikan dan pelatihan waralaba;

b. Rekomendasi untuk mengikuti pameran waralaba baik di dalam negeri maupun diluar negeri;

c. Bantuan konsultasi melalui klinik bisnis;

d. Penghargaan kepada pemberi waralaba lokal terbaik; dan/atau

e. Bantuan perkuatan permodalan.“

Hal yang menurut pendapat penulis perlu dikritisi dari rumusan pasal diatas adalah tidak adanya kejelasan pembagian mengenai poin mana yang merupakan tanggung jawab pemerintah dan mana yang menjadi tanggung jawab pemerintah daerah. Namun jika berbicara dari segi rumusan pasal, maka isi dari ketentuan pasal 14 ini sudah mengakomodir hal - hal yang perlu dilakukan dalam rangka membina waralaba yang ada di Indonesia hanya saja perlu kejelasan saja mana yang menjadi lingkup kewenangan pemerintah dan mana yang menjadi kewenangan pemerintah daerah.

Selanjutnya terkait dengan pengawasan, aturan yang lebih teknisnya dapat merujuk ke pasal 28 Permendagri No 53/M-DAG/PER/8/2012 yang berbunyi sebagai berikut ;

(1) "Menteri melimpahkan wewenang pengawasan pelaksanaan waralaba secara nasional kepada Direktur Jenderal Perdagangan Dalam Negeri.

(2) Dalam melaksanakan pengawasan sebagaimana dimaksud pada ayat (1) Direktur Jenderal Perdagangan Dalam Negeri dapat melakukan koordinasi dengan instansi terkait dipusat dan di daerah.

(3) Gubernur DKI Jakarta melimpahkan wewenang pengawasan pelaksanaan Waralaba diwilayah kerjanya kepada kepala Dinas yang membidangi perdagangan.

(4) Bupati/walikota melimpahkan wewenang pengawasan pelaksanaan Waralaba di wilayah kerjanya kepada Kepala Dinas yang bertanggungjawab di bidang perdagangan."

Dari pasal 28 ini dapat dipahami bahwa sudah ada kejelasan pembagian tugas antara Pemerintah pusat dan pemerintah daerah. Hanya tinggal perlu mengkritisi bagaimana implementasi dari pasal ini didalam kehidupan bermasyarakat yang mana berdasarkan hasil wawancara yang penulis lakukan diketahui bahwa untuk fungsi pengawasan, di kota Batam fungsi ini belum dijalankan oleh pemerintah kota Batam sebagaiamana seharusnya. Setelah ditelusuri lebih jauh penyebabnya adalah karena keterbatasan sumber daya manusia.

Dari yang sudah penulis jabarkan diatas, dapat disimpulkan bahwa mengacu dari teori efektivitas hukum ini utamanya dari faktor hukum, dari permasalahan yang dibahas dalam tesis ini dapat diketahui bahwa sudah ada aturan hukumnya yang membahas mengenai pengawasan dan pembinaan terhadap waralaba di Indonesia yaitu dengan dibentuknya PP No 42 tahun 2007 tentang Waralaba yang kemudian didukung dengan peraturan pelaksananya didalam Peraturan Menteri 
Perdagangan No 58/M-DAG/PER/8/2012 tentang penyelenggaraan Waralaba. Maka secara faktor hukum sudah baik. Sudah terpenuhi. Sudah ada landasan hukum yang mengatur mengenai pembinaan dan pengawasan terhadap waralaba hal yang masih perlu diperbaiki untuk segi faktor hukum adalah untuk bagian pembinaan terhadapa waralaba perlua adanya pembagian kerja yang jelas antara pemerintah pusat dan pemerintah daerah. Hal ini dapat diakomodir dengan membentuk suatu aturan turunan bisa pada level peraturan wali kota.

\section{Faktor Penegakan hukum}

Soerjono soekanto untuk aspek mengukur efektivitas hukum pada faktor ini, mengemukakakan yang pada intinya menjelaskan bahwa faktor penegakan hukum berkaitan dengan pihak - pihak yang diberikan kewenanagan untuk membentuk undang - undang dan juga yang berwenang untuk menerapkan hukum itu sendiri.

Aparatur penegak hukum ini memiliki tugas untuk dapat mencapai hal yang menjadi cita hukum yakni keadilan hukum, kepastian hukum, dan kemanfaatan hukum. Jika kita berbicara mengenai penegak hukum dalam arti sempit, maka hal ini berkaitan dengan pejabat seperti polisi, jaksa, hakim, dan penasehat hukum dan juga sipir lembaga pemasyarakatan (Lapas). Setiap aparat ini memiliki tugas masing - masing mulai dari menerima laporan, melakukan penyelidikan dan penyidikan, melakukan penuntutan dihadapan pengadilan kepada terdakwa, mengumpulkan dan menyampaikan bukti - bukti, memeriksa, mengadili dan menjatuhkan vonis, memberikan sanksi hingga melakukan pembinaan terhadap terpidana.

Terdapat tiga unsur utama yang memepengaruhi mekanisme bekerjanya aparat penegak hukum, yakni:

a. Instansi penegak hukum beserta dengan sarana dan prasarana yang menjadi pendukung dalam melaksanakan pekerjaan instansinya;

b. Budaya kerja dari aparat terkait termasuk juga sisi kesejahteraan dari aparat tersebut; dan

c. Instrumen hukum yang menjadi pendukung mulai dari kinerja instansinya maupun yang menjadi acuan standar bekerja dalam hal materiil maupun formalnya.

Dalam usaha mencapai tegaknya hukum secara sistematik memperhatikan ketiga unsur diatas menjadi sangat signifikan dan harus dilaksanakan secara simultan. Terkait dengan faktor penegak hukum disini, dapat diketahui bahwa dalam hal pelaksanaan pembinaan dan pengawasan bagi waralaba khususnya dibidang bimbingan belajar penegak hukumnya yang mana adalah Dinas Perindustrian, Perdagangan dan Energi Sumber Daya Mineral kota Batam serta Sub direktorat Penjualan Langsung dan Waralaba Kementrian Perdagangan Republik Indonesia. Kedua instansi ini adalah pihak yang dilimpahi kewenangan oleh hukum positif dalam hal memberikan pembinaan dan pengawasan terhadap waralaba. Namun berdasarkan hasil wawancara yang penulis lakukan dikatahui bahwa dari level Dinas Perindustrian, Perdagangan dan Energi Sumber Daya Mineral kota 
Batam tugasnya dalam hal memberikan pembinaan belum terlaksana. Disebabakan keterbatasan sumber daya sehingga amanah undang - undang terkait pembinaan dan pengawasan untuk waralaba di kota Batam memang belum pernah terlaksana.

Terkait dengan faktor ini dari hasil wawancara yang dilakukan diketahui memang sumber daya manusia memang masih sangat kurang di Dinas Perindustrian, Perdagangan dan Energi Sumber Daya Mineral kota Batam. Tidak hanya kekurangan dalam hal jumlah sumber daya manusianya, sumber daya manusia yang berkompeten juga belum ada untuk mengurusi masalah pengawasan dan pembinaan terhadap waralaba di Kota Batam.

Hal ini didukung juga oleh hasil wawancara yang penulis lakukan dengan salah pengelola waralaba bimbingan Primagama yang ada di Kota Batam, yaitu, dari hasil wawancara yang penulis lakukan memang benar pemerintah kota batam tidak ada keterlibatannya dalam hal memberikan pembinaan dan pengawasan bagi usaha waralaba khususnya dibidang bimbingan belajar yang ada di kota batam.

\section{Faktor Sarana atau Fasilitas Hukum}

Yang menjadi titik fokus pada faktor ini adalah perlunya dukungan dari sarana dan fasilitas hukum agar tercapai tujuan yakni hukum yang efektif dimasyarakat. Contoh dari sarana dalam faktor ini bisa berupa sarana fisik seperti bangunan, peralatan yang memadai, anggaran yang cukup dan alat transportasi. sedangkan untuk fasilitas pendukung dapat berupa tenaga manusia yang kompeten, terampil dan memiliki kemampuan organisasi yang baik. Yang terjadi pada prakteknya sering suatu aturan perundang undangan telah disahkan namun sarana dan fasilitasnya belum tersedia, situasi seperti ini pada akhirnya menimbulkan konsekuensi situasi yang kontra produktif.

Terkait dengan faktor ini, hal yang bisa dikategorikan sebagai faktor sarana dan fasilitas hukum dalam pelaksanaan pembinaan dan pengawasan bagi waralaba dibidang bimbingan belajar di Kota Batam adalah ketersediaan kendaraan dinas, instrument pendukung melakukan pembinaan dan pengawasan bagi para pihak yang memiliki kewenangan untuk melaksanakan tugasnya sebagai pengawas maupun pembina, yang mana kewenangan ini dimiliki oleh Dinas Perindustrian, Perdagangan dan Energi Sumber Daya Mineral kota Batam di Kota Batam. Dengan dilengkapi kendaraan yang memadai dan didukung dengan instrument pembinaan dan pengawasan yang baik sebagai contoh matriks penilaian bagi waralaba, klinik bisnis untuk pengembangan usaha, maka hal ini akan mempermudah pihak yang bertugas. Namun belum ada penganggaran yang khusus terkait hal ini, maka terhadap faktor fasilitas dan sarana hukum belum tercapai.

\section{Faktor Masyarakat}

Pada dasarnya setiap aturan perundang - undangan yang dibuat adalah untuk tujuan tercapainya kedamaian dan kesejahteraan dimasyarakat. Namun pada 
prakteknya seringkali masyarakat memiliki opini - opini tertentu terhadap hukum. Dari hal ini dapat dipahami bahwa efektivitas hukum juga dipengaruhi oleh faktor kesadaran hukum dan keinginan masyarakat untuk mematuhi aturan yang sudah diberlakukan. Tingkat sadar hukum yang rendah dari masyarakat akan berimbas pada sulitnya penegak hukum untuk menegakkan hukum itu sendiri. Hal yang dapat menjadi solusi untuk meningkatkan kesadaran hukum pada masyarakat adalah dengan melakukan sosialisasi terhadap aturan hukum positif.

Terkait dengan faktor ke-empat yang dikemukakan oleh Soerjono Soekanto ini, dari hasil wawancara diketahui bahwa pada dasarnya pihak Dinas Perindustrian, Perdagangan dan Energi Sumber Daya Mineral kota Batam telah mengetahui perannya dalam hal memberikan pengawasan dan pembinaan bagi usaha waralaba. Jadi dapat disimpulkan sosialisasi terkait peraturan perundang - undangan yang membidangi urusan waralaba ini telah sampai kepada pihak dinas Perindustrian, Perdagangan dan Energi Sumber Daya Mineral kota Batam. Dari segi masyarakat, yang secara spesifik dibahas dalam penulisan tesis ini yakni pengelola usaha waralaba dibidang bimbingan belajar menyatakan tidak mengetahui bahwa secara hukum pihak pemerintah kota batam memiliki andil dalam hal membantu pembinaan bagi usaha waralaba. Yang terjadi prakteknya dilapangan, pengusaha waralaba mendapat pembinaan sekedar hanya dari pemberi waralaba (franchisor).

Terkait faktor masayarakat dalam efektivitas hukum, saya juga melakukan wawacara singkat dengan warga masyarakat sekitar tempat bimbel Primagama untuk mengetahui tingkat pengetahuan masyarakat soal pembinaan dan pengawasan waralaba. Pak Muhammad Afandi (28 tahun) menyatakan tidak mengetahui soal pembinaan dan pengawasan waralaba ini begitupun dengan $\mathrm{Bu}$ Anisul (50 Tahun) juga menyatakan tidak mengetahui soal pembinaan dan pengawasan bagi waralaba ini. Lebih lanjut penulis menanyakan lagi bagaimana tanggapan masyarakat mengetahui bahwa faktanya di Dinas Perindustrian, Perdagangan dan Energi Sumber Daya Mineral kota Batam fungsi pengawasan dan pembinaan ini tidak berjalan sesuai amanat undang - undang, tanggapan dari pak Muhammad Afandi dan bu Anisul terhadap hal ini adalah biasa - biasa saja. Dari hasil interview ini dapat dikatahui bahwa tingkat pemahaman masyarakat sendiri terkait hal ini masih sangat rendah. Masyarakat cenderung apatis terhadap pembinaan dan pengawasan bagi waralaba.

\section{Faktor Kebudayaan}

Untuk faktor kebudayaan jika dikaitkan dengan pembahasan dalam tesis ini dapat kita soroti dalam hal sikap masyarakat terkait aturan pembinaan dan pengawasan terhadap waralaba. Sebelum membahas mengenai sikap masyarakat terkait pembinaan dan pengawasan terhadap waralaba, perlu juga terlebih dahulu diketahui megenai tanggapan masyarakat terkait keberadaan bimbingan belajar.

Dari hasil wawancara diketahui bahwa masyarakat memandang positif keberadaan bimbingan belajar karena dianggap bisa menjadi alternatif bagi siswa yang memerlukan pembimbingan belajar untuk lebih memahami materi di sekolah. Dari wawancara yang penulis lakukan dengan masyarakat sekitar dapat diketahui 
juga bahwa masyarakat disekitar lokasi salah satu tempat berdirinya Bimbingan Belajar yang melaksanakan bisnisnya dengan metode waralaba terhadap pembinaan dan pengawasan bagi waralaba adalah bersikap acuh tak acuh. Bagi masyarakat hal ini bukan hal yang terlalu penting.

Berbicara mengenai faktor kebudayaan, pada dasarnya faktor ini merupakan satu kesatuan dengan faktor masyarakat. Dalam faktor kebudayaan ini pembahasannya memusatakan pada isu - isu terkait sistem nilai yang menjadi inti dari hal terkait kebudayaan spiritual atau nonmaterial. Sebagaimana yang diketahui, suatu sistem yang baik pada hukum mestilah mencakup hal yang baik juga bagi substansi, struktur dan juga kulturnya.

Soerjono Soekanto menyatakan, hukum barulah dikatakan efektif mana kala antara apa yang diamanatkan oleh hukum beriringan sejalan dengan tujuan yang diharapkan hukum. ${ }^{2}$ Suatu peraturan perundang - undangan dianggap efektif apabila tindakan yang dilakukan oleh aparat penegak hukum semakin mendekati yang diinginkan oleh undang - undang dan begitupun sebaliknya akan dianggap tidak efektif jika tindakan yang dilakukan oleh aparat penegak hukum semakin jauh dari diinginkan oleh undang - undang. ${ }^{3}$

\section{Solusi Menyelesaikan Problematika Pembinaan dan Pengawasan Waralaba dibidang Bimbingan Belajar di Kota Batam.}

Cita hukum adalah untuk memberikan keadilan, kepastian, dan kemanfaatan hukum. Setiap aturan yang dibuat harapannya adalah untuk dapat memberikan kesejahteraan dan ketentraman di masyarakat.

Pembentukan Peraturan Pemerintah No 42 Tahun 2007 tentang Waralaba jika kita merujuk kepada bagian penjelasan umum dari Peraturan Pemerintah tersebut diketahui bahwa tujuan awal dari pembentukan Peraturan Pemerintah ini adalah dalam rangka meningkatkan pembinaan usaha yang dijalankan dengan metode waralaba di seluruh Indonesia. Pembinaan dilaksanakan sebagai upaya untuk menstimulus pengusaha nasional lebih utamanya pengusaha UMKM untuk menjadi pemberi waralaba nasional handal yang memiliki daya saing di dalam negeri dan luar negeri, sehingga mampu untuk memasarkan produk lokal dipasar global.

Berdasarkan hasil penelitian yang penulis lakukan dengan melakukan wawancara kepada stakeholders terkait pembinaan dan pengawasan terhadap waralaba jenis usaha bimbingan belajar di kota Batam diketahui bahwa ketentuan mengenai pembinaan dan pengawasan waralaba yang termaktub didalam Pasal 14 - 15 Peraturan Pemerintah No 42 Tahun 2007 tentang Waralaba dan aturan teknisnya yang tercantum didalam Peraturan Menteri Perdagangan No 58/MDAG/PER/8/2012 tentang penyelenggaraan Waralaba masih belum berjalan sebagaimana mestinya.

\footnotetext{
${ }^{2}$ Soerjono Soekanto, Kesadaran Hukum dan Kepatuhan Hukum, Jakarta: Rajawali Pers, 1982 hlm. 115

${ }^{3}$ Soerjono Soekanto, Faktor-faktor yang Memengaruhi Penegakan Hukum, Jakarta: PT Raja Grafindo Persada, 2005, hlm. 9
} 
Dalam penerapannya di masyarakat, setiap aturan perundang undangan memiliki kendala dan problematikanya masing - masing. Kendala - kendala tersebut bisa jadi berasal dari hukumnya sendiri, dari aparat penegak hukumnya atau bisa jadi karena budaya hukum masyarakatnya. Dikemukakan oleh Soerjono Soekanto, untuk dapat berlaku secara efektif hukum harus didukung oleh 5 buah faktor yang mana jika kelima faktor ini berjalan dengan baik maka efektifnya pemberlakukan aturan tersebut dimasyarakat.

Dari data yang telah peneliti kumpulkan, baik data sekunder maupun data primer solusi yang diberikan untuk menyelesaikan problematika dalam penerapan Peraturan Pemerintah No 42 Tahun 2007 tentang waralaba dapat diuraikan sebagai berikut;

1. Faktor Hukum

Disebutkan didalam pasal 14 Peraturan Pemerintah No 42/2007 bahwa yang bertanggung jawab melakukan pembinaan bagi waralaba adalah pemerintah dan pemerintah daerah. Dan hal - hal yang menjadi lingkup dari pembinaan yang dilakukan oleh pihak pemerintah ataupun pemerintah daerah adalah sebagai berikut ;

a. "Pendidikan dan pelatihan waralaba;

b. Rekomendasi untuk mengikuti pameran waralaba baik di dalam negeri maupun diluar negeri;

c. Bantuan konsultasi melalui klinik bisnis;

d. Penghargaan kepada pemberi waralaba lokal terbaik; dan/atau

e. Bantuan perkuatan permodalan."

Hal yang menurut pendapat penulis perlu dikritisi dari rumusan pasal diatas adalah tidak adanya kejelasan pembagian mengenai poin mana yang merupakan tanggung jawab pemerintah dan mana yang menjadi tanggung jawab pemerintah daerah dalam melakukan pembinaan terhadap waralaba. Oleh karena itu sebaiknya dapat ditambahkan pada bagian penjelasan pasal demi pasal dari peraturan pemerintah ini untuk memberikan jabaran detail mengenai pembagian peran dari pemerintah pusat dan pemerintah daerah.

Selanjutnya terkait dengan pengawasan. Dapat merujuk ke pasal 28 Permendagri No 53/M-DAG/PER/8/2012 yang berbunyi sebagai berikut ;

(1) "Menteri melimpahkan wewenang pengawasan pelaksanaan waralaba secara nasional kepada Direktur Jenderal Perdagangan Dalam Negeri.

(2) Dalam melaksanakan pengawasan sebagaimana dimaksud pada ayat (1) Direktur Jenderal Perdagangan Dalam Negeri dapat melakukan koordinasi dengan instansi terkait dipusat dan di daerah.

(3) Gubernur DKI Jakarta melimpahkan wewenang pengawasan pelaksanaan Waralaba diwilayah kerjanya kepada kepala Dinas yang membidangi perdagangan.

(4) Bupati/walikota melimpahkan wewenang pengawasan pelaksanaan Waralaba di wilayah kerjanya kepada Kepala Dinas yang bertanggungjawab di bidang perdagangan." 
Dari pasal 28 ini dapat dipahami bahwa sudah ada kejelasan pembagian tugas antara Pemerintah pusat dan pemerintah daerah. Hanya saja untuk di kota Batam sendiri, berdasarkan hasil wawancara yang penulis lakukan diketahui bahwa untuk fungsi pengawasan, di kota Batam fungsi ini belum dijalankan oleh pemerintah kota Batam sebagaimana seharusnya. penyebabnya adalah karena keterbatasan sumber daya manusia. Solusi dari problem terkait faktor hukum ini adalah perlu adanya pengaturan secara lebih teknis mengenai waralaba ini didalam aturan turunan pada level peraturan walikota Batam, yang mana dari aturan ini dapat memberikan pengaturan yang lebih teknis dalam pelaksanaan pembinaan dan pengawasan waralaba di Kota Batam. Termasuk didalamnya memberikan penjelasan yang lebih rincian mengenai kewenangan yang dimiliki oleh Dinas Perindustrian dan Perdagangan dan Energi Sumber Daya Mineral dalam melaksanakan tuganya sebagai Pembina dan pengawas bagi waralaba yang ada di kota Batam.

2. Faktor Penegakan hukum

Terkait dengan faktor penegak hukum disini, dapat diketahui bahwa dalam hal pelaksanaan pembinaan dan pengawasan bagi waralaba khususnya dibidang bimbingan belajar penegak hukumnya yang mana adalah Dinas Perindustrian, Perdagangan dan Energi Sumber Daya Mineral kota Batam serta Sub direktorat Penjualan Langsung dan Waralaba Kementrian Perdagangan Republik Indonesia. Kedua instansi ini adalah pihak yang dilimpahi kewenangan oleh hukum positif dalam hal memberikan pembinaan dan pengawasan terhadap waralaba. Namun berdasarkan hasil wawancara yang penulis lakukan dikatahui bahwa dari level Dinas Perindustrian, Perdagangan dan Energi Sumber Daya Mineral kota Batam tugasnya dalam hal memberikan pembinaan belum terlaksana. Disebabakan keterbatasan sumber daya sehingga amanah undang - undang terkait pembinaan dan pengawasan untuk waralaba di kota Batam memang belum pernah terlaksana. Terkait dengan faktor ini dari hasil wawancara yang dilakukan diketahui memang fasilitas pendukung yang mencakup sumber daya manusia memang masih sangat kurang di Dinas Perindustrian, Perdagangan dan Energi Sumber Daya Mineral kota Batam.

Tidak hanya kekurangan dalam hal jumlah sumber daya manusianya, sumber daya manusia yang berkompeten juga belum ada untuk mengurusi masalah pengawasan dan pembinaan terhadap waralaba di Kota Batam. Hal ini didukung juga oleh hasil wawancara yang penulis lakukan dengan pengelola bimbingan belajar Primagama, dari hasil wawancara yang penulis lakukan memang benar pemerintah kota batam tidak ada keterlibatannya dalam hal memberikan pembinaan dan pengawasan bagi usaha waralaba khususnya dibidang bimbingan belajar yang ada di kota batam. Solusi dari permasalahan ini adalah perlu adanya usaha yang serius dari pihak pemerintah kota Batam untuk mengakomodir kebutuhan akan sumber daya manusia yang kompeten dibidang pengawasan dan pembinaan terhadap waralaba di Kota Batam serta perlu adanya pelaksanaan pelatihan bagi pegawai di Dinas Perindustrian dan Perdagangan Sumber Daya Mineral kota Batam agar dapat memenuhi kualifikasi untuk dapat melakukan pembinaan serta pengawasan terhadap waralaba yang ada di Kota Batam. 


\section{Faktor Sarana atau Fasilitas Hukum}

Terkait dengan faktor ini, hal yang bisa dikategorikan sebagai faktor sarana dan fasilitas hukum dalam pelaksanaan pembinaan dan pengawasan bagi waralaba dibidang bimbingan belajar di Kota Batam adalah ketersediaan kendaraan dinas, instrument pendukung melakukan pembinaan dan pengawasan bagi para pihak yang memiliki kewenangan untuk melaksanakan tugasnya sebagai pengawas maupun pembina, yang mana kewenangan ini dimiliki oleh Dinas Perindustrian, Perdagangan dan Energi Sumber Daya Mineral kota Batam di Kota Batam. Dengan dilengkapi kendaraan yang memadai dan didukung dengan instrument pembinaan dan pengawasan yang baik sebagai contoh matriks penilaian bagi waralaba, klinik bisnis untuk pengembangan usaha, maka hal ini akan mempermudah pihak yang bertugas.

4. Faktor Masyarakat

Faktor masyarakat juga berpengaruh bagi efektifnya peraturan perundang undangan. Masyarakat yang memiliki kesadaran hukum yang baik akan berbanding lurus dengan tingkat efektifnya peraturan perundang undangan. Solusi yang dapat untuk meningkatkan kesadaran hukum pada masyarakat adalah dengan dilakukannya sosialisasi yang lebih konkretnya dapat berupa pelaksanaan diseminasi kepada masyarakat yang terkait langsung dengan pembinaan dan pengawasan waralaba, diseminasi ini dengan melibatkan lapisan-lapisan sosial, pemegang kekuasaan dan penegak hukum itu sendiri sebab memang sudah seharusnya setiap perturan yang tealh ditetapkan untuk dilaksanakan didalam masyarakat untuk dapat menyentuh masyarakat. Sebab aturan yang ditetapkan namun tidak diketahui masyarakatnya sendiri akan menjadi tidak berguna.

5. Faktor Kebudayaan

Untuk faktor kebudayaan jika dikaitkan dengan pembahasan dalam tesis ini dapat kita soroti dalam hal sikap masyarakat terkait aturan pembinaan dan pengawasan terhadap waralaba. Dari hasil wawancara yang penulis lakukan diketahui bahwa masyarakat bersikap acuh tak acuh terhadap pembinaan dan pengawasan waralaba bagi bimbingan belajar di kota Batam. Solusi dari hal ini adalah perlu adanya pemberian arahan ataupun membuka pemahaman masyarakat, jika pembinaan dan pengawasan bagi waralaba dapat berlangsung dengan maksimal maka juga akan memberikan dampak positif bagi kemajuan bimbingan bimbingan belajar yang ada di kota Batam, yang sebagai efek dominonya juga akan dirasakan oleh peserta didik dari bimbingan belajar tersebut.

\section{E. Kesimpulan}

Dengan mengguakan teori efektivitas hokum menurut Soerjono Soekanto dapat ditarik kesimpulan bahwa pengaturan mengenai pembinaan dan pengawasan terhadap waralaba belum diterapkan secara efektif. 
Problematika dalam penerapan Peraturan Pemerintah No 42 tahun 2007 tentang waralaba terhadap pembinaan dan pengawasan waralaba adalah sebagai berikut :

a. Faktor penegak hukum : Kurangnya sumber daya manusia dan tenaga yang kompeten dalam melakukan pembinaan dan pengawasan terhadap waralab di Kota Batam

b. Faktor sarana atau fasilitas hukum : Belum ada sarana dan prasana yang khusus dialokasikan guna mendukung pelaksanaan pembinaan dan pengawasan bagi waralaba di bimbingan belajar primagama di Kota Batam

c. Faktor masyarakat : tingkat kesadaran masyarakat terhadap hukum masih rendah.

d. Faktor kebudayaan : budaya hukum masyarakat yang masih bersifat pasif terhadap suatu aturan tertentu.

Solusi dalam mengatasi problematika dari penerapan Peraturan Pemerintah No

42 tahun 2007 tentang waralaba terhadap pembinaan dan pengawasan waralaba adalah sebagai berikut :

a. Faktor hukum : Perancangan Peraturan Walikota Batam sebagai aturan yang lebih teknis dalam mengatur pembinaan dan pengawasan waralaba di kota Batam.

b. Faktor penegak hukum : Pemerintah kota Batam mengakomodir kebutuhan sumber daya manusia yang kompeten dibidang pengawasan dan pembinaan terhadap waralaba di Kota Batam.

c. Faktor sarana atau fasilitas hukum : Pengalokasian anggaran khusus untuk menunjang pelaksanaan pembinaan dan pengawasan waralaba di Kota Batam.

d. Faktor masyarakat : Dinas Perindustrian dan Perdagangan dan Energi Sumber Daya Mineral Kota Batam melakukan sosialisasi kebijakan terkait pembinaan dan pengawasan waralaba.

e. Faktor Kebudayaan : mengedukasi masyarakat pentingnya kesadaran akan hukum.

DAFTAR PUSTAKA

Buku 
B.,I. L Pasaribu, Simanjuntak. Membina dan Mengembangkan Generasi Muda. Bandung : Tarsito, 1990

Burton Simatupang, Richard. Aspek Hukum Dalam Bisnis. Jakarta : Rineka Cipta, 2007

Hamalik, Oemar. Perencanaan Pengajaran Berdasarkan Pendekatan Sistem. Jakarta : Bumi Aksara, 2004

Helmi, Masdar. Dakwah dalam Alam Pembangunan I. Semarang : Semarang Toha Putra. 1973

Karamoy, Amir. Percaturan Waralaba Indonesia. Jakarta : Foreignsight Asia. 2013

Salim, Peter dan Yenny Salim. Kamus Bahasa Indonesia Kontemporer. Jakarta : Modern English Perss. 2002

Soekanto, Soerjono. Pokok-pokok Sosiologi Hukum. Jakarta : PT Raja Grafindo Persada. 2007

Soekanto, Soerjono. Kesadaran Hukum dan Kepatuhan Hukum. Jakarta : Rajawali Pers. 1982

Soekanto, Soerjono. Faktor-faktor yang Memengaruhi Penegakan Hukum. Jakarta : PT Raja Grafindo Persada. 2005

Syaodih, Nana dan Sukmadinata. Landasan Psikologi Proses Pendidikan. Bandung : Remaja Rosdakarya. 2003

Widjaja, Gunawan. Lisensi atau Waralaba Suatu Panduan Praktis. Jakarta : Raja Grafindo Persada. 2004

Yusuf, Syamsu dan Juntika Nurihsan. Landasan Bimbingan dan Konseling. Bandung : Remaja Rosdakarya. 2008

\section{Sumber Internet}

http://kbbi.web.id/

https://www.primagama.co.id/

http://www.bi.go.id/id/umkm/kelayakan/pola-

pembiayaan/perdagangan/Documents/ffe3421401fd4332beca78a62c41bc99Bimb

el.pdf

http://eprints.uny.ac.id/9331/3/bab\%202-08208241006.pdf

http://eprints.walisongo.ac.id/6616/3/BAB\%20II.pdf

https://www.scribd.com/doc/54689510/Pengertian-Pengawasan

http://digilib.unila.ac.id/3584/13/BAB\%20II.pdf

\section{Perundang - Undangan}

Undang - Undang Dasar Negara Republik Indonesia Tahun 1945

Undang - Undang No 20 Tahun 2003 Tentang Sistem Pendidikan Nasional

Undang - Undang No 7 Tahun Tahun 2014 Tentang Perdagangan

Undang - Undang No 20 Tahun 2008 Tentang Usaha Mikro, Kecil dan Menengah (UMKM)

Peraturan Pemerintah No 42 Tahun 2007 Tentang Waralaba

Peraturan Menteri Perdagangan No 58/M-DAG/PER/8/2012 Tentang

Penyelenggaraan Waralaba 
